\title{
Needle blight of pine caused by two species of Dothistroma in Hungary
}

\author{
I. Barnes ${ }^{1}$, T. Kirisits ${ }^{2}$, M. J. Wingfield ${ }^{1}$ and B. D. Wingfield ${ }^{1}$
}

(1) Department of Genetics, Forestry and Agricultural Biotechnology Institute (FABI), University of Pretoria, Pretoria 0002, South Africa.

(2) Forest Pathology and Forest Protection (IFFF), Department of Forest and Soil Sciences (DFS), Institute of Forest Entomology, University of Natural Resources and Life Sciences, Vienna (BOKU), Austria.

\section{Irene Barnes}

Email: irene.barnes@fabi.up.ac.za

\begin{abstract}
Dothistroma septosporum and D. pini cause the serious pine needle disease, Dothistroma needle blight (DNB). Of these, D. septosporum has a global distribution, while $D$. pini is known only from the USA, Russia, Ukraine and France. During a study of D. septosporum isolates from Pinus nigra in Hungary, microsatellite markers revealed the presence of a second Dothistroma species. The aim of this study was to identify the DNB pathogens occurring in Hungary using four different molecular techniques. These included sequencing of the rDNA ITS region, a species-specific ITSRFLP, mating type primers and a diagnostic microsatellite marker, Doth_A. Results showed that both D. septosporum and D. pini occur in Hungary and that both DNB pathogens were present on the same trees and in some cases, the same needles. Mating types MAT1 and MAT2 of $D$. septosporum were shown to be present in Hungary, but only the MAT2 of $D$. pini was found. In addition, examination of needles with DNB symptoms from Russia revealed the presence of $D$. pini on Pinus pallasiana and P. nigra as well as on a new host, Pinus mugo. The molecular markers applied in this study were sufficiently robust to identify and differentiate between the two DNB pathogens, both in culture and directly from needles. They will consequently be useful to document the geographical range and to monitor the spread of $D$. septosporum and $D$. pini in future studies.
\end{abstract}

\section{Introduction}

The disease known as Dothistroma needle blight (DNB) is characterized by red bands surrounding black, erumpent conidiomata that split the epidermal layers of infected pine needles. These needles become necrotic, are cast, and after successive defoliation, the disease can result in stunted tree growth (Gibson 1972; van der Pas 1981). When infection is severe, mortality can occur in highly susceptible Pinus spp. (Karadzić 1988; Woods 2003). The disease has caused major epidemics on Pinus radiata D. Don (Monterey pine) in the Southern Hemisphere, particularly in Central Africa, Chile, New Zealand and Australia (Gibson 1972; Bradshaw 2004). In recent decades, it has also been increasing in incidence and severity in the Northern Hemisphere. Currently, serious epidemics are occurring on Pinus contorta var. latifolia Dougl. Loud. (lodgepole pine) in British Colombia (Woods 2003; Woods et al. 2005) and on Pinus nigra Arnold subsp. laricio (Poiret) Maire (Corsican pine) in Britain (Brown and Webber 2008). 
Two very similar ascomycete fungi are known to cause DNB (Barnes et al. 2004). Dothistroma septosporum (Dorog.) Morelet (teleomorph: Mycosphaerella pini Rostr.) is the pathogen responsible for the epidemics mentioned earlier and has a worldwide distribution. It infects more than 82 different pine species (Watt et al. 2009) within and outside their native ranges (Maschnig and Pehl 1994; Aumonier 2002; Woods 2003; Bradshaw 2004; Kehr et al. 2004; Kirisits and Cech 2006). In contrast to D. septosporum, Dothistroma pini Hulbary (telemorph: unknown) has only been found in the North-Central USA on P. nigra J. F. Arnold and in the bordering countries of Ukraine and South-Western Russia, on P. pallasiana D. Don (Barnes et al. 2004, 2008a). More recently, Ioos et al. (2010) reported $D$. pini on P. nigra in France and, for the first time, the occurrence of both DNB pathogens in the same area. The original native ranges of the two Dothistroma species are unknown. Likewise, it is not known whether they differ in their host preferences or virulence to various pine species.

The morphological characteristics of the two DNB fungi are very similar with the only credible difference being the width of the conidia (Barnes et al. 2004, 2008a). On both infected needles and in culture, conidia of $D$. pini are on average slightly wider than those of $D$. septosporum (Barnes et al. 2008a). Because of their almost identical morphology and ability to cause the same disease, DNA-based methods provide the only unambiguous route to distinguish between the two species.

Sequencing of gene regions including the rDNA ITS, $\beta$-tubulin and the translation elongation factor (EF1- $\alpha$ ) genes has shown that D. septosporum and D. pini differ phylogenetically and reside in two distinct lineages (Barnes et al. 2004). In addition to real-time PCR diagnostic methods available (Ioos et al. 2010), these species can also be identified using an ITS-RFLP diagnostic procedure (Barnes et al. 2004) and two sets of species-specific mating type primers designed by Groenewald et al. (2007). Another approach that is useful for screening large populations of isolates is the microsatellite primer pair, Doth_A (Barnes et al. 2008b). This primer can be used as a diagnostic marker in genescan analyses as the locus amplified is monomorphic for allele 124 in $D$. septosporum and 114 in D. pini (Barnes et al. 2008b). These alleles also differ in their sequences (see GenBank accession nos: EF591826 for D. septosporum and EF591827 for D. pini).

Recently, DNB has been regularly reported from new areas and having an increased intensity in pine plantations of Hungary. In a preliminary screening of isolates collected from infected P. nigra trees in this country, the microsatellite diagnostic marker, Doth_A, revealed the presence of a different allele of $109 \mathrm{bp}$, possibly that of $D$. pini, in addition to the 124-bp allele of $D$. septosporum (Barnes et al. 2008b; Barnes 2009). The aim of the present investigation was to confirm the identity and establish the mating type of the Dothistroma needle blight pathogen/s causing the epidemics on P. nigra in two areas in Hungary using ITS sequence data. Three of the diagnostic methods described earlier were used in this study to determine their validity and robustness for species identification without the need to sequence. In addition, their usefulness in identifying $D$. septosporum and $D$. pini directly from needles without first making isolations was assessed. Infected needles with typical DNB symptoms from two locations in Russia were also included in this study to identify the causal agent of those infections.

\section{Materials and Methods}

\section{Sampling}

Pinus nigra needles affected by DNB were collected in May 2007 from two areas on dolomite sites in the highlands of Lake Balaton, Hungary (Fig. 1). One collection site was a small pine stand planted alongside the road near the village Diszel. Here, trees were 12-15 years old and a handful of infected needles were collected from every second tree. The second collection site was in Csabrendek (Bakonyerdő, Forestry and Timber Industry Co. unit Devecser), where 18-year-old 
trees growing in a plantation were sampled (Figs 1 and 2). A handful of needles were collected from every second tree along vertical and horizontal transects. All collected needles were placed separately into paper bags, transported to the laboratory and stored at $-80^{\circ} \mathrm{C}$ until they could be further processed.

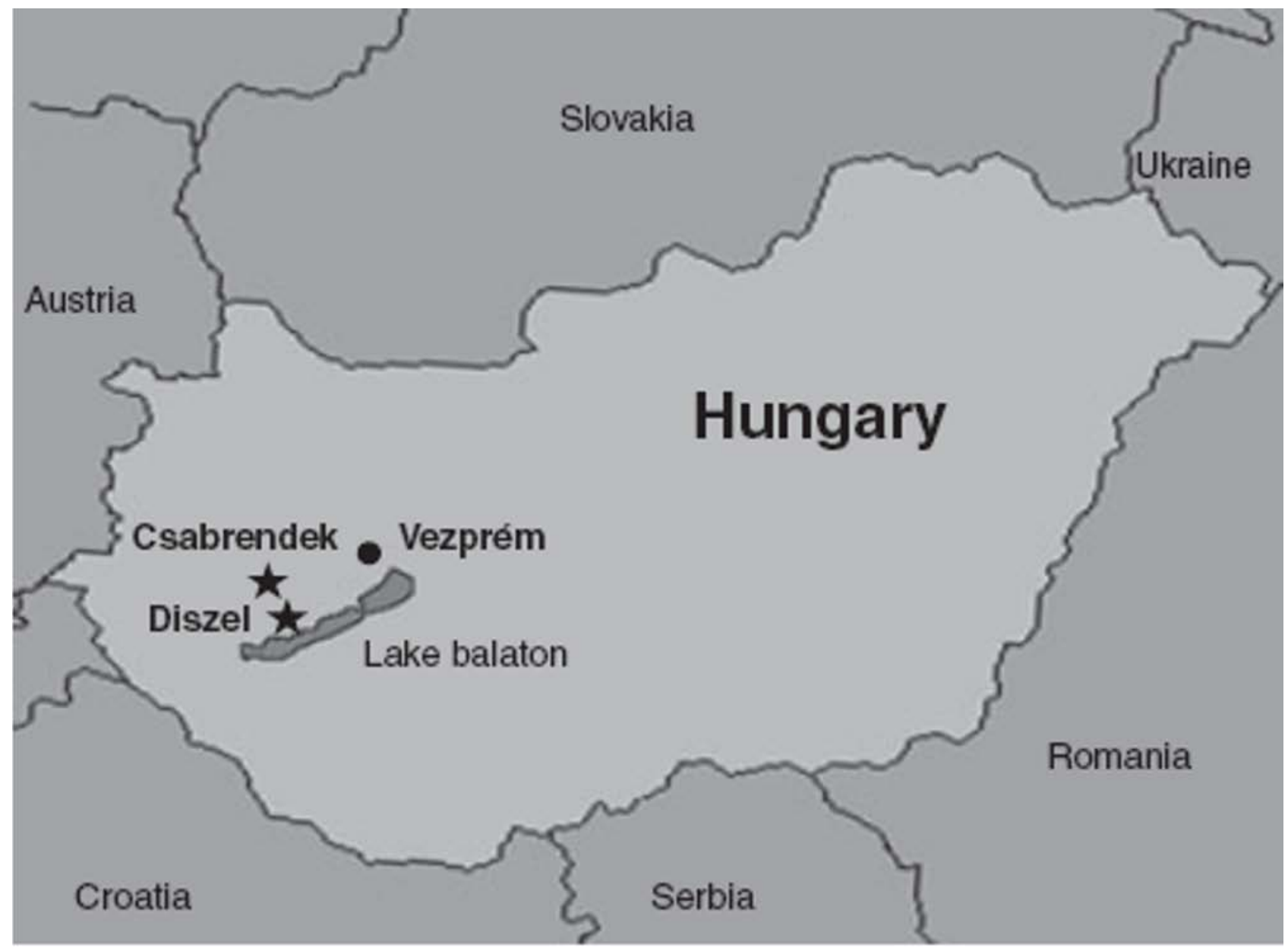

Figure 1. Location of collection sites in Hungary in Csabrendek (Bakonyerdő, Forestry and Timber Industry Co.) and near the village of Diszel.

Needles from Russia were collected from two different districts and from three different host species including Pinus mugo Turra (Dwarf mountain pine), $P$. pallasiana (Crimean pine) and $P$. nigra (Austrian pine) (Table 1). They were sent to the Forestry and Agricultural Biotechnology Institute (FABI) for species identification and were included in this study.

\section{Fungal isolation and DNA extraction}

\section{Diszel and Russia}

Fungal isolation and DNA extraction from the material collected near Diszel were carried out as part of a previous study (Barnes 2009). Cultures linked to this material as well as those from the Russian material were obtained by isolating single conidia from one mature conidioma on a needle, per tree, and growing these on 2\% malt extract agar (MEA, Biolab, Midrand, Johannesburg, South Africa) plates at $18^{\circ} \mathrm{C}$ for $4-6$ weeks. Isolations from conidiomata were carried out as described by Barnes et al. (2004), with the exception that the agar block containing conidia was turned conidialside down and used to spread the conidia on a plate to separate them from each other. As single conidia germinated, they were then transferred to clean MEA plates for further growth. Fungal colonies for DNA extraction were scraped clean of excess agar, freeze-dried and crushed using the Retsch GmbH MM301 mixer mill (Haan, Germany). Total DNA was extracted from the crushed 
mycelium using the DNeasy Plant Mini Kit (Qiagen, Hilden, Germany).
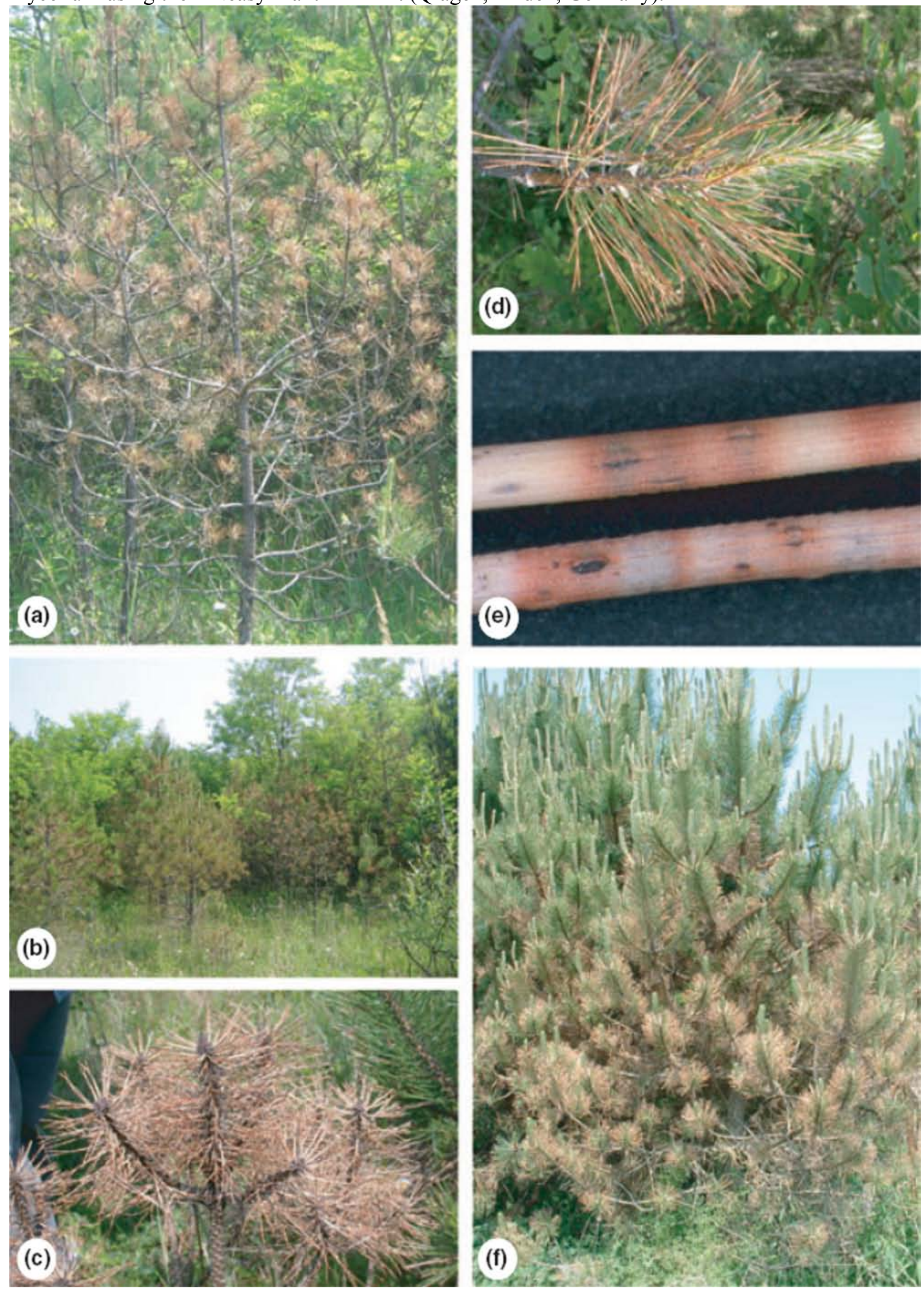

Figure 2. Dothistroma needle blight on Pinus nigra in Hungary: (a) a severely infected tree at the Csabrendek collection site (Bakonyerdő, Forestry and Timber Industry Co.); (b) 18-year-old, 
infected trees in the same compartment; (c) a small, young tree showing mortality; (d) infected 2year-old needles will soon be cast and provide the source of inoculum for infection of the 1-year-old needles; (e) typical red band symptoms with black asexual fructifications (conidiomata) of the DNB fungi; (f) 12-15-year-old trees at the collection site near the village of Diszel.

Table 1. Collection data of Dothistroma septosporum and Dothistroma pini isolates from Hungary and Russia used for rDNA ITS sequencing in this study.

\begin{tabular}{|c|c|c|c|c|c|}
\hline Country & Location & Host & Host age (years) & Fungal species & Isolate number \\
\hline \multirow[t]{2}{*}{ Hungary } & Casbrendek (Bakonyerds, & P. nigra & 18 & D. pini & $\mathrm{CMW}^{t} 29371$ (CBS 127874) ${ }^{2}$, CMW 29374 \\
\hline & $\begin{array}{l}\text { Forestry and Timber } \\
\text { Industry Co. unit Devecser) }\end{array}$ & P. nigra & 18 & D. septosporion & CMW 29372, C.MW 29373 (CBS 127656) \\
\hline \multirow[t]{2}{*}{ Hungary } & Near Diszel: trees alongside the road & P. nigra & $12-15$ & D. $p \dot{p i r}$ & $\begin{array}{l}\text { CMW } 26395 \text { (CBS 127657), CMW 26398, } \\
\text { CMW 26405, CMW 26407, CMW 26412, } \\
\text { CMW 26417, CMW 26422, CMW 26424, } \\
\text { CMW 26436, CMW 26437, CMW 2644, } \\
\text { CMW 26442, CMW 26443 }\end{array}$ \\
\hline & & P. nigra & $12-15$ & D. septosporson & $\begin{array}{l}\text { CMW } 26397 \text { (CBS 127658), CMW 26410, } \\
\text { CMW 26416, CMW 26448 }\end{array}$ \\
\hline Russia & $\begin{array}{l}\text { Tarasovsky district, } \\
\text { Gorodishchensky timber } \\
\text { enterprise, Gorodishchenskoye } \\
\text { forestry }\end{array}$ & P. pallasiana & 10 & D. $p \dot{v i i}$ & CMW 29366, CMW 29367 \\
\hline \multirow[t]{3}{*}{ Russiz } & Krasnosulinsky district, & P. nigra & 30 & D. $p \dot{v i n}$ & CMW 29368 (CBS 127871) \\
\hline & Donskoye forestry & P. pallasiana & 25 & D. pini & CMW 29369 (CBS 127872) \\
\hline & & P. mago & 7 & D. pini & CMW 29370 (CBS 127873) \\
\hline
\end{tabular}

'CMW numbers refers to the isolates that were sequenced in this study and that are mantained in the culture collection of the Forestry and Agricultural Biotechnology Institute (FABI), University of Pretoriz, South Africa, 0002.

${ }^{2}$ Representative isolates deposited at the Centralbureau voor Schimmelcultures (CBS), Utrecht, The Netherbands.

\section{Csabrendek}

For the collection made in Csabrendek, a more structured isolation strategy was adopted. Two needles were randomly selected from each of 10 trees (tree 1-10). From the first needle, single conidia were isolated from a single conidioma (as seen in Fig. 2e) and plated onto MEA. From the second needle, two conidiomata were excised and single-conidial isolations were made from each of these (Fig. 3). Additional isolations were made from conidiomata on needles from trees 4 and 8. All single-conidial isolates were grown at $18^{\circ} \mathrm{C}$ until their colony sizes had reached $2-3 \mathrm{~mm}$ in diameter. The colonies were then crushed manually, and the DNA was extracted using $100 \mu \mathrm{l}$ PrepMan Ultra Sample Preparation reagent following the manufacturers protocol (Applied Biosystems, Foster City, CA, USA).

To determine whether the DNB pathogen/s could be identified directly from needles without the need to first isolate the fungus, DNA was extracted from complete conidiomata on the needles from trees 4 and 8. Each single conidiomatal structure, observed under a microscope, was cut out of the needle using a sterile scalpel. After removing excess plant material, the entire conidioma was placed directly into an Eppendorff tube. To extract DNA from the sample, $10 \mu$ l PrepMan Ultra reagent was added, the tube vortexed and then heated for $10 \mathrm{~min}$ at $100^{\circ} \mathrm{C}$. From these crude and rapid extractions, $0.5 \mu \mathrm{l}$ of the supernatant was used in subsequent PCRs.

\section{DNA analyses}

\section{Sequencing}

For the Diszel material, the ITS region of 13 isolates that contained the unknown 109-bp allele and four that contained the 124-bp D. septosporum allele, as determined in a previous study (Barnes 2009), was sequenced to determine, or confirm, their identities (Table 1). In addition, four isolates obtained from the Csabrendek material and all five isolates from Russia were also sequenced (Table $1)$. 


\section{Tree 4, Needle 4}

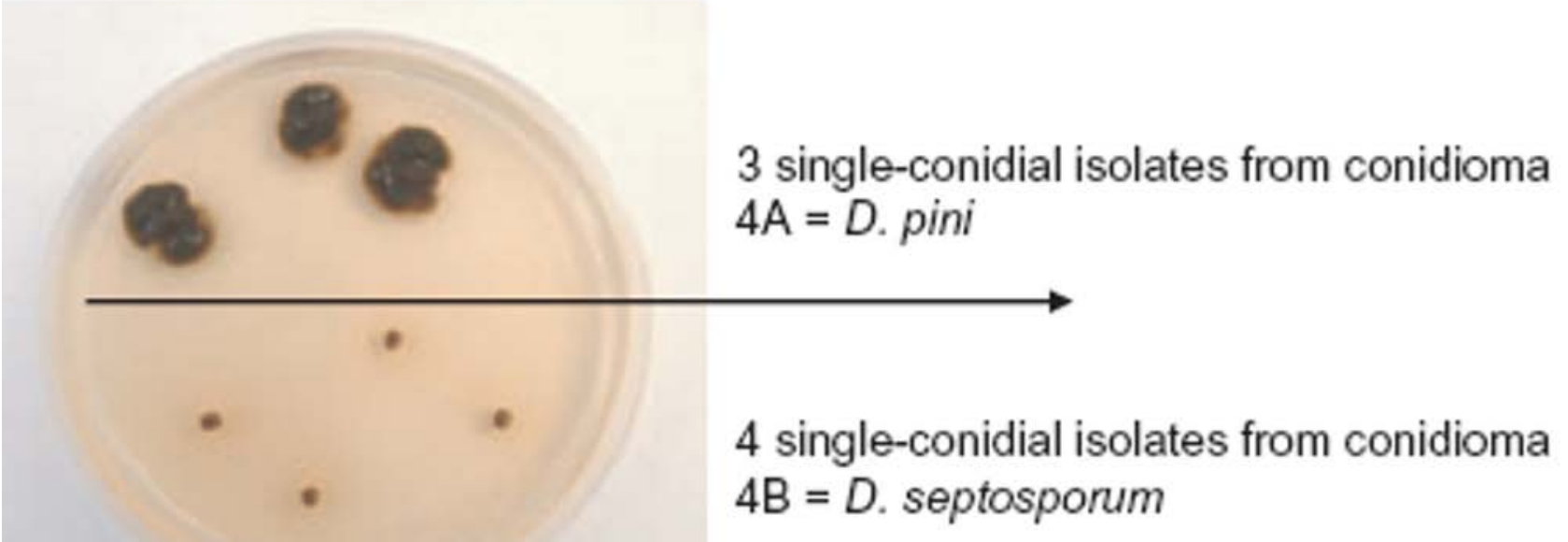

Figure 3. Different cultural characteristics observed when single-conidial isolates were made from different conidiomata on the same needle (tree 4, needle 4). Conidioma 4A produced isolates of Dothistroma pini while conidioma 4B produced D. septosporum isolates.

The ITS1, 5.8S and ITS2 regions of the ribosomal RNA operon were amplified using the primers ITS1 and ITS4 (White et al. 1990) as described in Barnes et al. (2004). These products were purified using G-50 sephadex (SIGMA-Aldrich, Steinheim, Germany) in Centri-sep Spin Columns (Princeton separations Inc., Adelphia, USA). Sequencing reactions were prepared using Big Dye v 3.1 (Applied Biosystems) and run on an ABI PRISM ${ }^{\mathrm{TM}} 3100$ capillary autosequencer (Applied Biosystems). Sequences were analysed using VECTOR NTI 10.3.0 Advance software (Invitrogen, Carlsbad, CA, USA) and aligned online, using MAFFT version 6 (http://align.bmr.kyushuu.ac.jp/mafft/online/server/). Default settings were used with the strategy set at L-INS-I (Katoh et al. 2005). Parsimony analyses using the heuristic search option with tree bisection-reconnection (TBR) and 100 random stepwise-additions were selected in PAUP* Version 4.0b10 (Phylogenetic Analysis Using Parsimony) (Swofford 2002). Bootstrap confidence limits for the branching nodes were determined using 1000 replicates. Neofusicoccum ribis (Slippers, Crous \& M.J. Wingf.) Crous, Slippers and A.J.L. Phillips was used as the outgroup in the phylogenetic analyses.

\section{Primer Doth_A}

For all DNA samples, the microsatellite locus DMS_A (GenBank accession no: EF591826) was amplified using the forward primer Doth_A(F)-(FAM): 5'CGG CAT CAC TGT TCA CCA CGC3' and the reverse primer Doth_A(R): 5'GAA GCC GCA AGT GCC AAT GGC3' as described by Barnes et al. (2008b). The annealing temperature was set at $58^{\circ} \mathrm{C}$. Fluorescent PCR products were run on an ABI PRISMTM 3100 capillary autosequencer (Applied Biosystems), and allele sizes were determined using GENEMAPPER ${ }^{\mathrm{TM}}$ software version 3.0 (Applied Biosystems).

\section{RFLP}

The species-specific RFLP patterns for the DNB fungi (Barnes et al. 2004) were generated by restricting the purified ITS amplicons with the restriction enzyme AluI following the protocol recommended by the supplier (Fermentas Life Science, Glen Burnie, MD, USA). The resultant DNA fragments were subjected to 3\% agarose gel electrophoresis. Dothistroma pini was considered present if samples produced two fragments of approximately $170 \mathrm{bp}$ and $350 \mathrm{bp}$ in size. Amplicons that were not digested by the enzyme represented $D$. septosporum. This ITS-RFLP species identification method was used on all the single-conidial isolates obtained from Csabrendek. It was 
not used on DNA from whole conidiomata because of the possible amplification of other contaminating plant and/or fungal material.

\section{Mating type}

The DNB species-specific mating type primers (Groenewald et al. 2007) were used to confirm the identity of selected isolates from Csabrendek as determined using the ITS-RFLP patterns. They were also used for species identification in the whole-conidiomata DNA samples. Mating types were determined for the D. pini isolates from Dieszel and Russia in this study and the D. pini isolates from Ukraine and Russia in the study by Barnes et al. (2008b). The species-specific primers amplify regions of approximately $820 \mathrm{bp}$ and $480 \mathrm{bp}$ for MAT1 and MAT2 in D. pini and $823 \mathrm{bp}$ and $480 \mathrm{bp}$ for MAT1 and MAT2 in D. septosporum. PCRs and conditions were the same as those described by Groenewald et al. (2007).

\section{Results}

\section{Fungal isolation and DNA analyses}

\section{Diszel and Russia}

From the Diszel collection, the four chosen isolates containing the 124-bp microsatellite allele (Table 1) all had ITS sequences identical to those of D. septosporum from Europe (Fig. 4). The 13 isolates that produced the 109-bp allele (Table 1) were grouped within the D. pini clade and had ITS sequences identical to strains from $P$. nigra in the USA. Similarly, the isolates from $P$. mugo, $P$. nigra and $P$. pallasiana from Russia (Table 1) had identical ITS sequences to those from Ukraine on P. pallasiana and were identified as D. pini (Fig. 4).

\section{Csabrendek}

A total of 28 isolates were obtained from the 10 trees sampled at Csabrendek (Table 2). Twentythree isolates contained the 124-bp allele for primer pair Doth_A, and all the ITS-RFLP products were of the same size as the undigested controls (Table 2). This confirmed that these isolates were all D. septosporum (Table 2). The five remaining isolates from tree 4 and tree 8 each produced a 109-bp allele at the locus Doth_A. In addition, the ITS amplicons from these isolates were digested by the restriction enzyme $A l u \mathrm{I}$, adding further confidence that these isolates represent $D$. pini (Table 2).

Sequences of the ITS region confirmed the results obtained with the diagnostic markers (Doth_A and ITS-RFLP). Isolates N1 from tree 4 (CMW 29374) and N2B from tree 8 (CMW 29371) (Tables 1 and 2) were grouped in the $D$. pini clade from the USA, and isolates N1 from tree 5 (CMW 29372) and N2A from tree 7 (CMW 29373) (Tables 1 and 2) were grouped in the D. septosporum clade (Fig. 4). For six isolates from tree 4 and five from tree 8, species identification applying the mating type primers was fully consistent with the results obtained using the two other diagnostic markers (Doth_A and ITS-RFLP, Table 2).

For the whole-conidioma investigations (Table 3), application of the mating type primers, six of the seven examined conidiomata produced amplicons of $480 \mathrm{bp}$ with the $D$. pini-specific primers. This indicated that $D$. pini was present and that they were all MAT2. This result was confirmed with the Doth_A primer, where the same isolates produced the 109-bp allele, indicating D. pini. The speciesspecific mating type primers also showed that D. septosporum was present in all seven conidiomata with amplicons of $480 \mathrm{bp}$ representing MAT1 and $823 \mathrm{bp}$ representing MAT2. The presence of $D$. septosporum was confirmed in these samples using the microsatellite marker Doth_A that amplified 
the 124-bp allele. Both mating type genes of $D$. septosporum were found in a single conidioma from tree 8 (conidioma 2, Table 3).

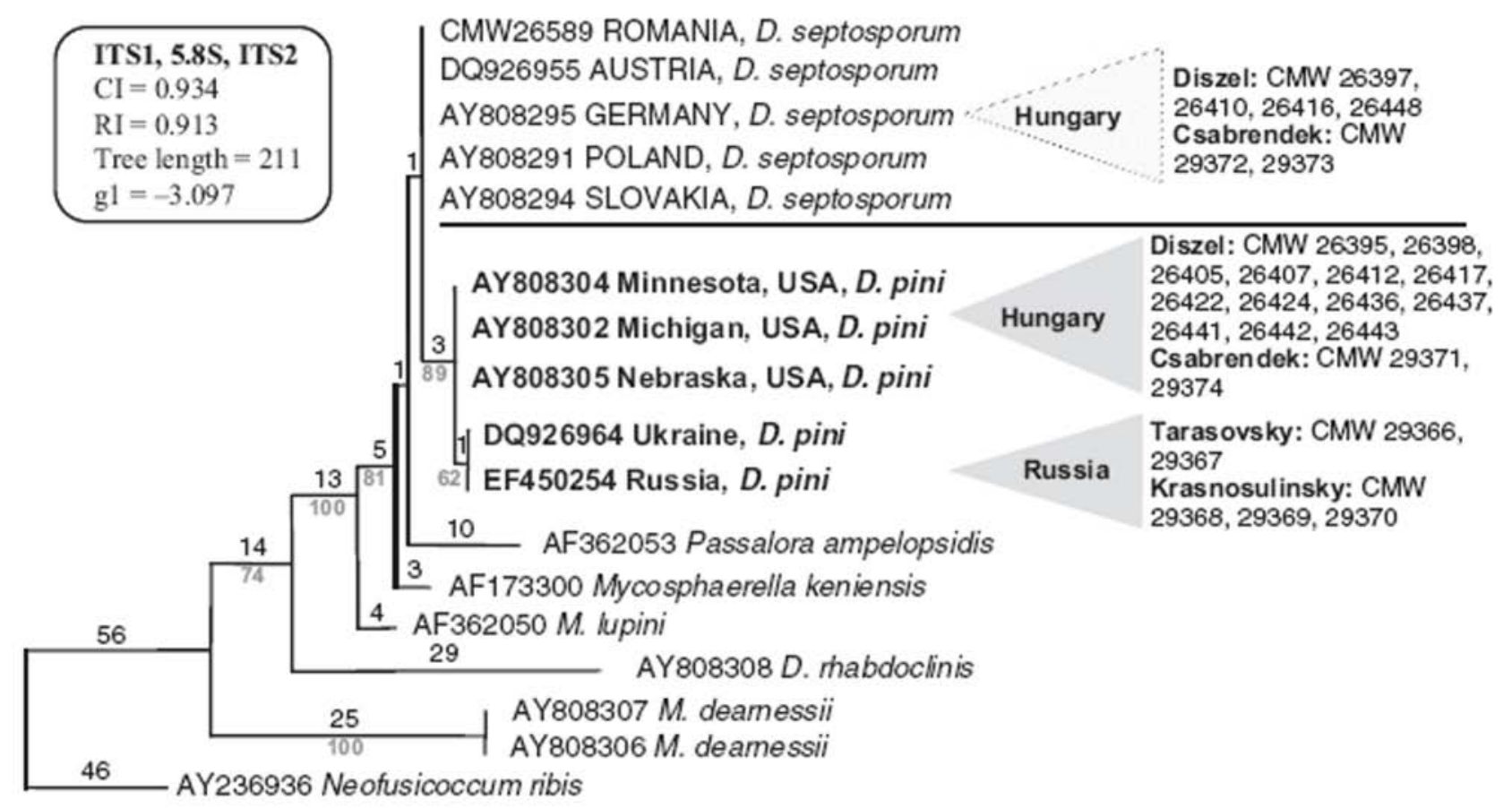

Figure 4. Phylogram of the Dothistroma needle blight isolates from Hungary and Russia based on maximum parsimony analyses of the ITS sequences. Of 475 total characters, 312 were constant, 101 variable characters were parsimony-uninformative and 62 were parsimony-informative. Isolates from Hungary, from both collection areas (Diszel and Csabrendek), contain isolates that group into the Dothistroma septosporum and D. pini (in bold) clades. All the Russian isolates are D. pini. The isolates sequenced in this study had $100 \%$ similarity to the representative isolates from GenBank in each clade. Isolates sequenced from Romania, Hungary and Russia with CMW numbers are maintained in the culture collection of FABI. Tree lengths (above) and bootstrap values (below) are indicated on the branches.

\section{Mating type}

All 23 isolates (Tables 1 and 2, Fig. 4) and the six DNA extracts from needles (Table 3) identified as D. pini in this study, from both localities in Hungary and Russia represented only the MAT2 mating type gene. Additionally, isolates from Russia (CMW 24852 and CMW 24853) and Ukraine (CMW 23767, CMW 23768 and CMW 23769), already identified as D. pini by Barnes et al. (2008b) were screened and were all of the MAT2 type.

\section{Discussion}

This study represents the first report of the pine needle pathogen, D. pini in Hungary, where it was present at two collection sites. In addition, D. septosporum was found at the same locations, on the same trees and even infecting the same needles. Among the samples included from Russia for identification purposes, $D$. pini was found at two new locations, confirming the previous report of this fungus from that country (Barnes et al. 2008a). The Russian isolate from $P$. mugo represents a new host record for $D$. pini, and this pathogen is also reported for the first time from $P$. nigra in Russia. 
Table 2. Characterization and mating type of Dothistroma isolates obtained from the needle collection at Csabrendek based on ITS-RFLP banding patterns, the allele size (in base pairs) obtained using the microsatellite marker Doth_A and species-specific mating type primers.

\begin{tabular}{|c|c|c|c|c|c|}
\hline Tree & Isolate $^{1}$ & ITS-RFLP & Doth_A allele & Species & Mating type \\
\hline \multirow[t]{3}{*}{ Tree 1} & N1 & $--^{2}$ & - & - & \\
\hline & $\mathrm{N} 2 \mathrm{~A}$ & 1 band & 124 & D. septosporum & \\
\hline & N2B & 1 band & 124 & D. septosporum & \\
\hline \multirow[t]{3}{*}{ Tree 2} & N1 & 1 band & 124 & D. septosporum & \\
\hline & $\mathrm{N} 2 \mathrm{~A}$ & - & - & - & \\
\hline & N2B & - & - & - & \\
\hline \multirow[t]{3}{*}{ Tree 3} & N1 & 1 band & 124 & D. septosporum & \\
\hline & $\mathrm{N} 2 \mathrm{~A}$ & 1 band & 124 & D. septosporum & \\
\hline & N2B & 1 band & 124 & D. septosporum & \\
\hline \multirow[t]{7}{*}{ Tree 4} & N1 (CMW 29374) ${ }^{3,4}$ & 2 bands & 109 & D. pini & MAT-2 \\
\hline & $\mathrm{N} 2 \mathrm{~A}$ & - & - & - & \\
\hline & N2B & 1 band & 124 & D. septosporum & MAT-2 \\
\hline & $\mathrm{N} 3 \mathrm{~A}$ & 1 band & 124 & D. septosporum & MAT-1 \\
\hline & N3B & 1 band & 124 & D. septosporum & MAT-2 \\
\hline & $\mathrm{N} 4 \mathrm{~A}$ & 2 bands & 109 & D. pini & MAT-2 \\
\hline & N4B & 1 band & 124 & D. septosporum & MAT-2 \\
\hline \multirow[t]{3}{*}{ Tree 5} & N1 (CMW 29372) & 1 band & 124 & D. septosporum & \\
\hline & $\mathrm{N} 2 \mathrm{~A}$ & 1 band & 124 & D. septosporum & \\
\hline & $\mathrm{N} 2 \mathrm{~B}$ & 1 band & 124 & D. septosporum & \\
\hline \multirow[t]{3}{*}{ Tree 6} & N1 & 1 band & 124 & D. septosporum & \\
\hline & $\mathrm{N} 2 \mathrm{~A}$ & - & - & - & \\
\hline & $\mathrm{N} 2 \mathrm{~B}$ & 1 band & 124 & D. septosporum & \\
\hline \multirow[t]{3}{*}{ Tree 7} & N1 & 1 band & 124 & D. septosporum & \\
\hline & N2A (CMW 29373) & 1 band & 124 & D. septosporum & \\
\hline & $\mathrm{N} 2 \mathrm{~B}$ & 1 band & 124 & D. septosporum & \\
\hline \multirow[t]{5}{*}{ Tree 8} & N1 & 2 bands & 109 & D. pini & MAT-2 \\
\hline & $\mathrm{N} 2 \mathrm{~A}$ & 1 band & 124 & D. septosporum & MAT-1 \\
\hline & N2B (CMW 29371) & 2 bands & 109 & D. pini & MAT-2 \\
\hline & N3A & 2 bands & 109 & D. pini & MAT-2 \\
\hline & N3B & 1 band & 124 & D. septosporum & MAT-1 \\
\hline \multirow[t]{3}{*}{ Tree 9} & N1.1 & 1 band & 124 & D. septosporum & \\
\hline & $\mathrm{N} 2 \mathrm{~A}$ & - & - & - & \\
\hline & $\mathrm{N} 2 \mathrm{~B}$ & - & - & - & \\
\hline \multirow[t]{3}{*}{ Tree 10} & N1 & 1 band & 124 & D. septosporum & \\
\hline & $\mathrm{N} 2 \mathrm{~A}$ & 1 band & 124 & D. septosporum & \\
\hline & $\mathrm{N} 2 \mathrm{~B}$ & - & - & - & \\
\hline
\end{tabular}

${ }^{1}$ From each of 10 trees, a single-conidial isolate from a conidioma was obtained from one needle ('N1') and one single conidial isolate each from two conidiomata from a second needle ('N2A' and 'N2B'). Exceptions are tree 4 and tree 8, where fungal isolations were obtained from additional needles.

2،-' Isolations were not successful because of either contamination or non-viable conidia.

${ }^{3}$ Two isolates of each $D$. pini and D. septosporum (those with CMW numbers, see Table 1 and Fig. 4) were sequenced to validate the robustness of the diagnostic markers.

${ }^{4}$ Trees containing both DNB species are indicated in bold font. 
Table 3. The identity and the mating type of the DNB fungi present within conidiomata taken directly from needles of tree 4 and tree 8 from Csabrendek (see Table 2) as determined using the Dothistroma species-specific mating type primers and the microsatellite marker Doth_A.

Species-specific mating type primers

\begin{tabular}{|c|c|c|c|c|c|}
\hline Tree & Conidioma & $\begin{array}{c}\text { Dotbistroma } \\
\text { pini }\end{array}$ & D. septosporum & $\begin{array}{l}\text { Allele 1: } \\
\text { D. pini }\end{array}$ & $\begin{array}{c}\text { Allele 2: } \\
\text { D. septosporum }\end{array}$ \\
\hline \multirow[t]{2}{*}{ Tree 4} & 1 & - & MAT2 & - & 124 \\
\hline & 2 & MAT-2 & MAT-1 (shadow band) & 109 & - \\
\hline \multirow{5}{*}{ Tree 8} & 1 & MAT-2 & MAT-1 & 109 & 124 \\
\hline & 2 & MAT-2 & MAT- 1 and MAT- $2^{1}$ & 109 & 124 \\
\hline & 3 & MAT-2 & - & 109 & 124 \\
\hline & 4 & MAT-2 & MAT-2 (shadow band) & 109 & - \\
\hline & 5 & MAT-2 & MAT-1 & 109 & 124 \\
\hline
\end{tabular}

${ }^{1}$ The text in bold font indicates the presence of both mating types of $D$. septosporum within a single conidioma/fruiting body.

Results of this study emphasise the usefulness of various newly developed DNA-based tools (Barnes et al. 2004, 2008b; Groenewald et al. 2007), as an alternative or in addition to real-time PCR diagnostic markers (Ioos et al. 2010) to discriminate between the two morphologically and ecologically similar DNB pathogens. They also show that it is possible to screen for these pathogens directly from conidiomata without first isolating them in pure culture, using the speciesspecific mating type primers and providing a confirmation of the result with the microsatellite primer set Doth_A. While this provides a useful and efficient approach for diagnosis, utilization of the Doth_A microsatellite primers alone is not recommended. This marker can distinguish between the DNB pathogens based on allele size, but it is not species-specific and has been shown to amplify DNA in other closely related species (Barnes et al. 2008b).

The ability of the DNB pathogens to share the same niche is evident by the presence of both $D$. pini and D. septosporum on the same needle, and furthermore, by their simultaneous detection in single conidiomata. Several species infecting a single necrotic lesion or spot is not uncommon and has been reported for pathogens on Eucalyptus (Crous et al. 2009). Dothistroma spp. infect pine needles via the stomata (Gadgil 1967; Peterson and Walla 1978), and it is therefore possible that several individuals of the same, or different species, can enter the stomata simultaneously and co-infect the same area of tissue. Several explanations are thus possible for the detection of both DNB pathogens when carefully extracting a single fruiting body directly from a needle. Owing to the close proximity of the fungi in the needles, conidiomata of both species could develop directly adjacent to each other, but erupt through a single opening in the epithelial tissue and thus appear to represent a single fruiting body. This is especially probable on heavily infected needles. Alternatively, the mycelium of both species could become intermixed in the plant tissue forming a multilocular conidioma composed of both species. Another explanation is that one species produces conidia in a single conidioma, while the second species is present as mycelium in the tissue and, although not visible using microscopy, is still detected through the sensitive DNA screening procedures. As whole-conidioma diagnostic assays all involved PCR, cross-contamination with epiphytic sources (mainly conidia) of $D$. pini and D. septosporum is possible.

Support for niche sharing in the DNB pathogens was found in the detection of multiple individuals from the same species in the whole-conidioma investigations. Both mating types of the heterothallic D. septosporum were found in what appeared to be a single asexually formed fruiting body. The occurrence of both mating types of D. septosporum in Hungary supports the results of Groenewald et al. (2007), who also found both mating types among D. septosporum isolates from Austria and Poland. The close proximity of isolates of opposite mating type would increase the chance of sexual 
reproduction and the development of the teleomorphic stage (pseudothecia), which is consistent with observations regarding the development of pseudothecia by Butin (1985). The teleomorph of D. septosporum, M. pini, was, however, not observed in this study, although it is known to occur in Europe (Butin 1985; Kowalski and Jankowiak 1998).

It is unlikely that sexual reproduction is occurring in D. pini in parts of Europe where the fungus has been detected. All the isolates of this species collected in Hungary, Russia and Ukraine and examined in this study are of the same mating type (MAT2). The second mating type has thus far not been recorded in Europe although isolates from France have, to the best of our knowledge, not yet been screened. This may suggest that either a single introduction of D. pini has occurred or that limited introductions of only MAT2 isolates have occurred in various parts of Europe. The presence of $D$. pini on $P$. nigra in Hungary might suggest that the source area of introduction into Europe could be the USA, where both mating types of the pathogen are present on $P$. nigra (Groenewald et al. 2007). However, if $D$. pini is indigenous to the USA, its native hosts remain unknown as the fungus has thus far only been found on P. nigra, which is not native in North America.

The introduction of the DNB fungi into Hungary is thought to have originated in neighbouring Serbia (A. Koltay, personal communication), where the disease has been known since 1955 (Krstić 1958). Marincović and Strajković (1969), and Karadzić (1988) noticed DNB appearing on trees growing on sandy soils in parts of Serbia located near the southern part of Hungary. In 1990, the pathogen (as D. septospora) was identified in an 11-year-old $P$. nigra stand near the town of Veszprém (I. Szabó, personal communication), and a few years later, during 1994-1995, large outbreaks of the disease began to occur throughout the country (Szabó 1997). Today, P. nigra, mainly as the subspecies or variety austriaca Aschers. \& Graebn (Austrian pine), occurs widely in Hungary and occupies an area of 69000 ha, corresponding to $4.1 \%$ of the forested area (ÁESZ Hungary 2002). DNB is present in most of these stands (Koltay 2007). From Hungary, the disease is thought to have spread northwards into Slovakia and was first reported in this country in 1996 (Zúbrik et al. 2006). Today, DNB is present in all regions of Slovakia (Zúbrik et al. 2006). Because there are few strict geographical barriers in Europe, pathogen spread between countries is typically difficult to control. The discovery of $D$. pini at two locations in Hungary and its presence in France (Ioos et al. 2010) suggest that it might also be present in other parts of Europe. It is thus highly likely that $D$. pini will spread to countries neighbouring Hungary if it is not already present but yet to be detected. Introduction of $D$. pini into Hungary could have been from neighbouring Ukraine. In the future, it will presumably show a pattern of spread in Europe similar to that of D. septosporum in the past.

During the last two decades, DNB has become a serious emerging forest disease and it is presently of concern to the custodians of pine plantations and pine forests globally. Particularly in Europe, the disease appears to be spreading rapidly and increasingly occurring at epidemic levels, with the newest reports of D. septosporum coming from Estonia on P. nigra (Hanso and Drenkhan 2008), Finland on Pinus taeda L., Pinus sylvestris L. and Picea abies (L.) Karst. (J. Huntula, personal communication), as well as from Sweden, on P. sylvestris (J. Stenlid, personal communication). Changing climatic conditions, particularly rising precipitation and temperatures, as well as changed precipitation patterns conducive for disease development, are key factors attributed to the recent increase in disease intensity in the Northern hemisphere (Woods et al. 2005; Brown and Webber 2008; Hanso and Drenkhan 2008). Recent epidemiological modelling of DNB indicated that host availability and susceptibility, and not climate, will be the limiting factors for future disease development in Europe (Watt et al. 2009).

In addition to providing new geographical and host reports of $D$. pini in Europe, we have shown that both the DNB pathogens occur in Hungary. Furthermore, this work supports that of Ioos et al. (2010) by documenting the co-existence of both species within a single needle. Originally it 
appeared that the geographical ranges of D. pini and D. septosporum do not overlap (Barnes et al. 2004, 2008a), which supported the theory of allopatric species divergence (Giraud et al. 2008). However, despite the discovery of $D$. pini within the distribution range of $D$. septosporum, the presence of only the MAT2 mating type of $D$. pini in Europe still strongly supports the view that the pathogen was introduced into this continent.

The increased risk or implication of the presence of both pathogens in a forest ecosystem is unknown because the evolutionary stresses and ecological processes leading to the genetic divergence of these pathogens have not been studied. In addition, nothing is known regarding differences in aggressiveness of genotypes or the relative ecological fitness of the two pathogens. Efforts aimed at reducing the impact of the disease could be hampered by the fact that the two species might respond differently to control measures (Bickford et al. 2007). Monitoring of DNB in Europe is thus likely to become increasingly important in the future. In this regard, accurate identification of the two pathogens causing this disease will be essential. Identifications in the past have mainly been based on morphology, and many reports are considered to be of dubious value. The molecular markers applied in this study and shown to be sufficiently robust to identify and discriminate between the two DNB pathogens should thus be useful tools for future scientific studies, disease surveys and plant quarantine.

\section{Acknowledgments}

We thank the Department of Science and Technology, the National Research Foundation and the Mellon Foundation, South Africa, for financial support. We thank Ilona Szabó for organizing the field trips during the IUFRO Working Party 7.02.02 meeting in Sopron, Hungary (21-26 May 2007), during which the needle samples used in this study were collected. Timur Bulgakov kindly supplied the Russian material, Ilona Szabó and András Koltay supplied invaluable information regarding DNB and Pinus nigra in Hungary and Barend Jansen van Vuuren provided laboratory technical assistance for which we are most grateful.

\section{Literature Cited}

ÁESZ Hungary, 2002: Magyarország erdóállományai 2001 [Hungarian forests 2001]. Állami erdészeti Szolgálat, Budapest.

Aumonier, T., 2002: La maladie des bandes rouges toujours en augmentation en [Dothistroma needle blight (Dothistroma septospora) still on the increase in 2001]. Les Cahiers du DSF, 1-2002 (La Santé des Forêts [France] en 2000 et 2001), Min. Agri. Alim. Pêche Aff. rur. (DERF), Paris, 5860.

Barnes, I., 2009: Taxonomy, phylogeny and population biology of the red band needle blight pathogen and related species. PhD thesis, University of Pretoria, Pretoria, South Africa.

Barnes, I.; Crous, P.W.; Wingfield, M.J.; Wingfield, B.D., 2004: Multigene phylogenies reveal that red band needle blight of Pinus is caused by two distinct species of Dothistroma, D. septosporum and D. pini. Stud. Mycol. 50, 551-565.

Barnes, I.; Kirisits, T.; Akulov, A.; Chhetri, D.B.; Wingfield, B.D.; Bulgakov, T.S.; Wingfield, M.J., 2008a: New host and country records of the Dothistroma needle blight pathogens from Europe and Asia. For. Pathol. 38, 178-195. 
Barnes, I.; Cortinas, M.N.; Wingfield, M.J.; Wingfield, B.D., 2008b: Microsatellite markers for the red band needle blight pathogen, Dothistroma septosporum. Mol. Ecol. Res. 8, 1026-1029.

Bickford, D.; Lohman, D.J.; Sodhi, N.S.; Ng, P.K.L.; Meier, R.; Winker, K.; Ingram, K.K.; Das, I., 2007: Cryptic species as a window on diversity and conservation. Trends Ecol. Evol. 22, 148-155.

Bradshaw, R.E., 2004: Dothistroma (red-band) needle blight of pines and the dothistromin toxin: a review. For. Pathol. 34, 163-185.

Brown, A.; Webber, J., 2008: Red band needle blight of conifers in Britain. Forestry Commission: Research Note.

Butin, H., 1985: Teleomorph- und anamorph-Entwicklung von Scirrhia pini Funk \& Parker auf Nadeln von Pinus nigra Arnold. [Teleomorph and anamorph development of Scirrhia pini Funk \& Parker of needles from Pinus nigra Arnold]. Sydowia, Annales Mycologici Ser. II 38, 20-27.

Crous, P.W.; Wingfield, M.J.; Groenewald, J.Z., 2009: Niche sharing reflects a poorly understood biodiversity phenomenon. Persoonia 22, 83-94.

Gadgil, P.D., 1967: Infection of Pinus radiata needles by Dothistroma pini. New Zeal. J. Bot. 5, 497-503.

Gibson, I.A.S., 1972: Dothistroma blight of Pinus radiata. Annu. Rev. Phytopathol. 10, 51-72.

Giraud, T.; Refrégier, G.; Le Gac, M.; de Vienne, D.M.; Hood, M.E., 2008: Speciation in fungi. Fung. Genet. Biol. 45, 791-802.

Groenewald, M.; Barnes, I.; Bradshaw, R.E.; Brown, A.; Dale, A.; Groenewald, J.Z.; Lewis, K.J.; Wingfield, B.D.; Wingfield, M.J.; Crous, P.W., 2007: Characterization and worldwide distribution of the mating type genes in the Dothistroma needle blight pathogens. Phytopathology 97, 825-834.

Hanso, M.; Drenkhan, R., 2008: First observations of Mycosphaerella pini in Estonia. Plant Pathol. $57,1177$.

Ioos, R.; Fabre, B.; Saurat, C.; Fourrier, C.; Frey, P.; Marc, ais, B., 2010: Development, comparison, and validation of real-time and conventional PCR tools for the detection of the fungal pathogens causing brown spot and red band needle blights of pine. Phytopathology 100, 105-114.

Karadzić , D., 1988: Dothistroma septospora (Dorog.) Morelet: rasprostranjenje, biljke domacini i znacaj [Dothistroma septospora: distribution, hosts and importance]. Glasnik Sumarskog Fakulteta, Univerzitet u Beogradu 70, 133-144.

Katoh, K.; Kuma, K.; Toh, H.; Miyata, T., 2005: MAFFT version 5: improvement in accuracy of multiple sequence alignment. Nucleic Acids Res. 33, 511-518.

Kehr, R.; Pehl, L.; Wulf, A.; Schrőder, T.; Kaminski, K., 2004: Zur Gefährdung von Bäumen und Waldökosystemen durch eingeschleppte Krankheiten und Schädlinge [Introduced pests and diseases as risks to trees and forest ecosystems]. Nachrichtenbl. Deut. Pflanzenschutzd. 56, 217-238.

Kirisits, T.; Cech, L.T., 2006: Entwickelt sich die Dothistroma-Nadelbräune zu einem Forstschutzproblem in Österreich? [Is Dothistroma needle blight going to become an important forest disease in Austria?]. Forstschutz Aktuell. 36, 20-26. 
(http://www.waldwissen.net/themen/waldschutz/pilze_nematoden/bfw_nadelbraeune_kiefer_2006_ DE).

Koltay, A., 2007: Susceptibility of different clone groups of Austrian pine to Mycosphaerella pini E. Rostrup and Sphaeropsis sapinea Dyko and Sutton. Acta Silvatica and Lignaria Hungarica, special edition. Proceedings of the Conference of IUFRO Working Party 7.02.02, 21-26 May, Sopron, Hungary, 47-51.

Kowalski, T.; Jankowiak, R., 1998: First record of Dothistroma septospora (Dorog.) Morelet in Poland: a contribution to the symptomology and epidemiology. Phytopatologia Polonica 16, 16-29.

Krstić, M., 1958: Nezabeležene fitopatološke pojave u rasadnicima i šumama Srbije. [Unnoted phytopathological phenomena in nurseries and forests of Serbia]. Zaštita bilja. 45, 75-79.

Marincović, P.; Strajković, B., 1969: Ogledi suzbijanja Dothistroma pini Hulbary u kulturama crnog bora na Deliblatskom Pesku. Deliblatski Pesak Zbornik radova I., 247-252.

Maschnig, E.; Pehl, L., 1994: Bedrohung autochthoner Latschen durch Dothistroma-Nadelbräune [Threat to authochthonous dwarf mountain pine by Dothistroma needle blight]. Allgemeine Forstzeitschrift, München 49, 249-252.

van der Pas, J.B., 1981: Reduced early growth rates of Pinus radiata caused by Dothistroma pini. N. Z. J. For. Sci. 11, 210-220.

Peterson, G.W.; Walla, J.A., 1978: Development of Dothistroma pini upon and within needles of Austrian and Ponderosa pines in Eastern Nebraska. Phytopathology 68, 1422-1430.

Swofford, D.L., 2002: PAUP*. Phylogenetic Analysis Using Parsimony (*and Other Methods). Version 4 Sunderland, Massachusetts: Sinauer Associates.

Szabó, I., 1997: A Dothistroma septosporum (Dorog.) Morlet fellépése feketefenyő-ültetvényeken [Occurrence of Dothistroma septospora in Austrian pine plantations]. Erdészeti Lapok 132, 44-45.

Watt, M.S.; Kriticos, D.J.; Alcaraz, S.; Brown, A.V.; Leriche, A., 2009: The hosts and potential geographic range of Dothistroma needle blight. Forest. Ecol. Manag. 257, 1505-1519.

White, T.J.; Bruns, T.; Lee, S.; Taylor, J., 1990: Amplification and direct sequencing of fungal ribosomal RNA genes for phylogenetics. In: PCR Protocols: A Sequencing Guide to Methods and Applications. Ed by Innis, M.A.; Gelfand, D.H.; Sninsky, J.J.; White, T.J. San Diego: Academic Press, pp. 315-322.

Woods, A.J., 2003: Species diversity and forest health in northwest British Columbia. For. Chron. 79, 892-897.

Woods, A.; Coates, K.D.; Hamann, A., 2005: Is an unprecedented Dothistroma needle-blight epidemic related to climate change? Bioscience 55, 761-769.

Zúbrik, M.; Kunca, A.; Turčani, M.; Vakula, J.; Leontovyc, R., 2006: Invasive and quarantine pests in forests in Slovakia. OEPP/EPPO Bulletin 36, 402-408. 